\title{
Understanding of Financial Literacy as a Moderating Variable on the Effect of Financial Technology on Financial Inclusion in Lubuklinggau City, Indonesia
}

\author{
Martini, Martini ${ }^{1} \square$ Sardiyo $^{2}$, Reza Septian ${ }^{3}$, Devi Anggreni Sy ${ }^{4}$ and Deni Nurdiansyah ${ }^{5}$ \\ 1245 Universitas Bina Insan, Indonesia \\ ${ }^{3}$ Badan penelitian dan Pengembangan Kabupaten Musi Rawas, Indonesia \\ $\square$ Corresponding Author: Martini, Martini, E-mail: Martinidhasman@univbinainsan.ac.id, ORCID ID: \\ https://orcid.org/0000-0002-3954-4254
}

ARTICLE INFORMATION

Received: 22 October 2021

Accepted: 10 November 2021

Published: 22 November 2021

DOI: $10.32996 /$ jefas.2021.3.2.14

\section{KEYWORDS}

Fintech, financial inclusion, financial literacy

\section{ABSTRACT}

This study investigates the effect of fintech on financial inclusion, and financial literacy, it was able to influence financial literacy on financial inclusion in Lubuklinggau. The research was conducted by distributing questionnaires to eight districts in the city of Lubuklinggau with a total sample of 401 people who use fintech as the main requirement. Data analysis was carried out with WarpPLS to identify direct and indirect effects on the tested variables. Based on the results, the perception of the ease and effectiveness of using fintech does not affect financial inclusion in Lubuklinggau. People are still not familiar with fintech and consider fintech as a new financial system and not easy to use. The level of risk and interest in using fintech has a significant influence on the financial inclusion variable in the Lubuklinggau. The indirect analysis explains it proves that financial literacy is able to moderate perceptions of the ease of using fintech and reduce the risk of fintech itself on financial inclusion. However, financial literacy is not able to moderate the effectiveness of using fintech and interest in financial inclusion to use of fintech after understanding financial literacy, people become more selective in using fintech.

\section{Introduction}

The spread of the Covid-19 virus has plagued Indonesia from early 2020 until now. Various efforts have been made starting from Lockdown, Large-Scale Social Restrictions (PSBB), and prohibiting any activities outside the home to stop the virus from spreading and taking more victims. Due to social restrictions and outside activities, it certainly has an impact on the Indonesian economy. This has an impact on the community's welfare, which has decreased because many businesses have closed, workers have been laid off (Termination of Employment) to reduce company losses and very limited economic activity.

This restriction does not stop the level of public consumption, many people use technology to continue to be able to carry out outside activities. One of the ways to do this is to make transactions online or commonly known as fintech (Financial technology) (Lee, 2018). Fintech is an innovation that provides convenience and comfort for the public in the financial sector because people can make transactions only with smartphones and the internet (Miswan Ansori, 2019). Financial Technology is an innovation in financial services by utilizing the development of information technology (NDRC, 2014). Financial Technology (Fintech) is a 'revolution' of combining financial services with information technology that has improved the quality of financial services quality and created financial stability (Commerce, 2016).

Fintech refers to the use of technology to provide financial solutions (Arner et al., 2015). Specifically, fintech is defined as the application of digital technology to financial intermediation problems (Aaron et al., 2017). Fintech is the use of financial system technology that produces new products, services, technology, and/or business models and can have an impact on monetary stability, financial system stability, efficiency, fluency, security, and reliability of the payment system (Bank Indonesia, 2017).

Copyright: (c) 2021 the Author(s). This article is an open access article distributed under the terms and conditions of the Creative Commons Attribution (CC-BY) 4.0 license (https://creativecommons.org/licenses/by/4.0/). Published by Al-Kindi Centre for Research and Development, London, United Kingdom. 
Changes in the pattern of financial transactions, provide new understanding for people who are required to be more understanding and technologically literate. The public must have a better understanding of the use of technology in managing finances. This understanding is called financial literacy. Financial literacy is the level of knowledge, skills, beliefs that influence attitudes and behavior to improve the quality of decision making and financial management in order to achieve prosperity (OJK, 2013). In addition, financial literacy is knowledge to manage finances (financial literacy is money management knowledge), indicators in financial literacy are (Titik Ulfatun, 2016):

1. Basic knowledge of financial management, this basic knowledge is usually related to making decisions in investing or financing that can affect a person's behavior in managing the money;

2. Credit management, facility to borrow money and repay it within a certain period of time with interest.

3. Savings management, the amount of money saved for future needs.

4. Investment management, A form of investment activity of funds or assets with the aim of obtaining profits in the future.

Public financial literacy will be better if it is followed by financial inclusion which also increases. Inclusion is providing financial services such as savings, credit, insurance, and payments at prices that all economic actors can afford, especially low-income economic actors (Anwar et al., 2017). Financial inclusion is the proportion of individuals and companies that use financial products and services (Pulungan \& Ndruru, 2019). Financial inclusion is the process of promoting affordable, timely, and adequate access to a wide range of regulated financial products and services and expanding their use by all segments of society through the adoption of existing and innovative tailored approaches including financial awareness and education with a view to promoting financial well-being and inclusion. economic and social (Holle, 2019). Financial inclusion is a banking instrument that plays an important role in financial service stability and financial access (Rusdianasari, 2018). The following indicators for financial inclusion are (Financial Service Authority Republic of Indonesia, 2018):

1. Availability/access

2. Usage

3. Quality

4. Welfare

The understanding of fintech on financial literacy and financial inclusion has a positive effect as evidenced by the fact that fintechbased financial services are needed by the community to broaden their horizons regarding financial literacy and financial inclusion (Mulasiwi \& Julialevi, 2020). This research is also reinforced by the Technology Acceptance Model (TAM) Theory which explains that people usually accept the use of technology in their daily activities because it is a new insight that facilitates activities using the technology so as to improve individual performance (Venkatesh \& Davis, 2000). This provides benefits for the community because of the ease of technology introduced in fintech which will improve financial literacy and financial inclusion of the community.

Technology Acceptance Model (TAM) Theory explains that there are two variables that influence individuals to use or not technology, perceptions of ease of use and perceptions of usefulness (Sulistiyarini, 2012).

TAM theory has 5 basic things:

1. Perceived usefulness

Perceived Usefulness can be divided into several dimensions as follows:

a. The use of the system can improve individual performance (improves job performance)

b. The use of the system can increase individual productivity (increases productivity)

c. The use of the system can increase the effectiveness of individual performance (enhances effectiveness)

d. The use of the system is useful for individuals (the system is useful).

2. Perceived ease of use

Technology is said to have ease of use if it has the following indicators:

a. Easy and skilled in using technology.

b. Technology can be easily learned.

c. Very easy to operate

3. Attitude towards behavior or attitude towards using technology

4. Behavioral intention to use technology 
The interest of each individual depends on the factors that influence it, each individual has their own interests. Although individuals have the same interest in something, they are motivated by certain factors. There are several indicators that can be used to measure interest, including:
a. Sense of Using
b. Always use
c. Continue to use in the future

5. Use of actual technology

This convenience is also relevant to the Theory of Planned Behavior (TBP) that people accept technology if it provides benefits for them. This theory can explain that trust and risk can influence individuals in the interest or desire to use technology. The Theory of Planned Behavior (TBP) has the advantage of being able to analyze situations when individuals cannot control their behavior (Sulistiyarini, 2012).

The use of fintech has increased financial literacy and public financial inclusion (Mulasiwi \& Julialevi, 2020). This is also supported by the two theories explained earlier that technology is accepted in society when people feel they receive benefits and get convenience with the use of the technology. This theory proves that Indonesia has progressed towards financial inclusion and literacy. Indonesia continues to experience an increase in financial literacy and inclusion amid the use of fintech which is increasingly in demand by the public. Various regions, both big cities and rural areas, have begun to use fintech in all activities, especially finance.

Based on the description, research was carried out on the understanding of fintech which is currently being widely used by the millennial generation both in conducting transactions, especially financial. Previous research is still limited to the influence of fintech on financial literacy and the influence of fintech on financial inclusion with indicators that are not yet specific. Therefore, researchers are interested in examining the effect of understanding fintech on financial inclusion with financial literacy as a moderating variable. This needs to be done as a form of welcoming the industrial revolution 4.0 by using technology in community activities to provide convenience for its users.

This study aims to develop previous research on the effect of fintech-based financial services on financial literacy and financial inclusion and at the same time want to know the variables that can affect the level of financial literacy and financial inclusion of the community. In addition, this research serves as consideration and additional information in formulating strategies to increase financial literacy and financial inclusion, especially those related to the provision of fintech-based financial services to be able to encourage the achievement of the Financial Services Authority's objectives in increasing financial literacy and financial inclusion of the Indonesian people.

The following is the framework of thinking in this research:

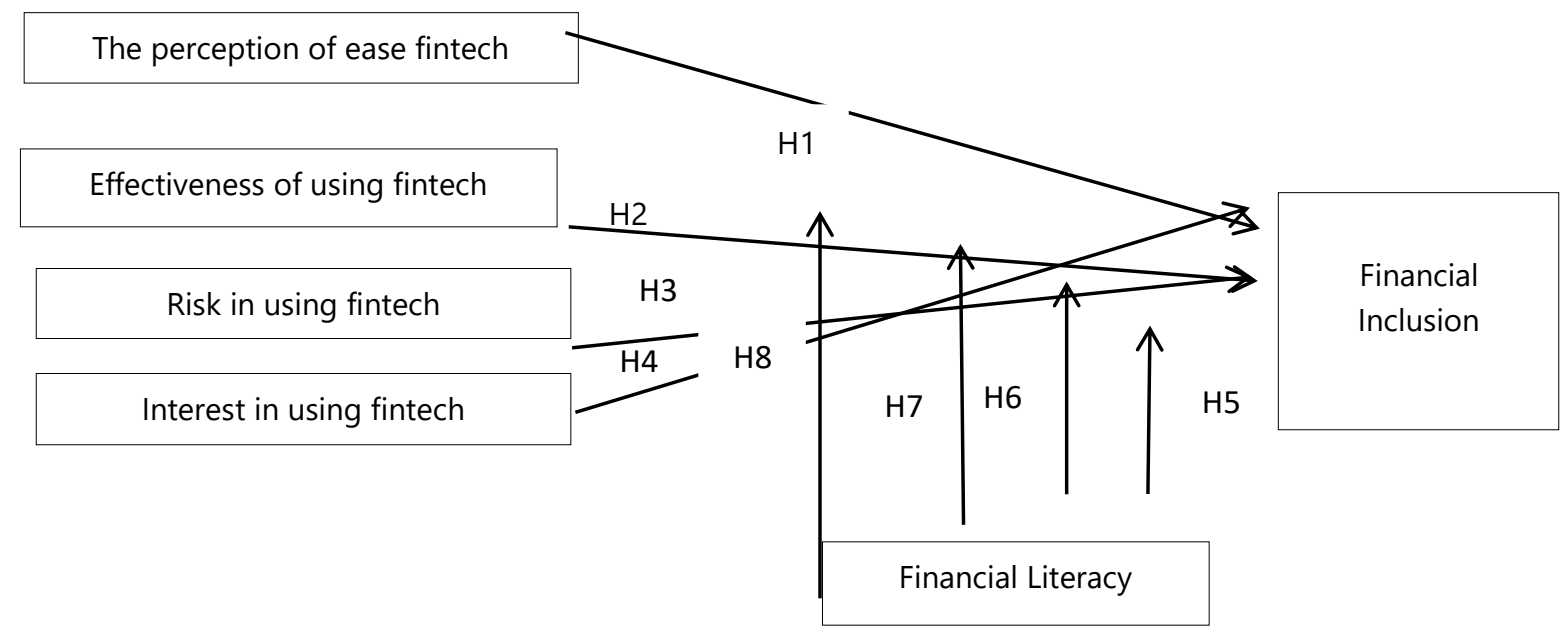

Figure 1. Framework of Research

Source: Primary data processed, 2020 
Based on the framework of research, the following hypotheses can be presented:

$\mathrm{H} 1$ : Perception of the ease of use of fintech affects financial inclusion

$\mathrm{H} 2$ : The effectiveness of using fintech affects financial inclusion

$\mathrm{H} 3$ : The risk of using fintech affects financial inclusion

$\mathrm{H} 4$ : Interest in transacting using fintech affects financial inclusion

H5: Financial literacy strengthens the effect of perceived ease of use of fintech on financial inclusion

H6: Financial literacy strengthens the effect of the effectiveness of using fintech on financial inclusion

$\mathrm{H7}$ : Financial literacy strengthens the effect of risk using fintech on financial inclusion

$\mathrm{H} 8$ : Financial literacy strengthens the influence of interest in transacting using fintech on financial inclusion

\section{Method}

\subsection{Research Design}

The classification of this research design is in the form of quantitative descriptive research that explains empirical phenomena accompanied by statistical data, characteristics, and patterns of relationships between variables. This study uses a survey method as a way to collect data. The survey was conducted by giving a questionnaire containing statements to respondents, namely all people who have used smartphones in Lubuklinggau City. The measurement method in this study uses a Likert scale with four scales (1-4) which is used to determine a person's assessment of something.

The questionnaire proposed consists of 1) Characteristics of respondents, including gender, latest education, and income earned. 2) Questionnaires related to the variables studied, namely perceptions of the ease of using fintech, the effectiveness of using fintech, risks of using fintech, interest in using fintech financial inclusion, and financial literacy.

The object of the research is the use of fintech, financial inclusion, and financial literacy for the people of Lubuklinggau City. The research variable consists of the dependent and independent variables. The dependent variable is financial inclusion. The independent variable is the perception of the ease of using fintech, the effectiveness of using fintech, the risk of using fintech, interest in using fintech and the moderating variable is financial literacy.

\subsection{Research Location}

This research was conducted on all residents of Lubuklinggau city by distributing questionnaires to each district in Lubuklinggau City. There are 8 districts in Lubuklinggau City. The distribution of questionnaires is done by dividing the number of respondents based on the population of each district so that each district has a different number of respondents. Respondents were selected randomly based on the conditions encountered in the field. The sample selection was carried out to the general public over the age of 17 years to 60 years and using a smartphone as a requirement for taking research data.

The following sub-districts in Lubuklinggau are as follows:

Table 1. Number of Districts in Lubuklinggau

\section{No Nama Kecamatan}

1 District of Lubuklinggau Barat I

2 District of Lubuklinggau Barat II

3 District of Lubuklinggau Timur I

4 District of Lubuklinggau Timur II

5 District of Lubuklinggau Utara I

6 District of Lubuklinggau Utara II

7 District of Lubuklinggau Selatan I

8 District of Lubuklinggau Selatan II

Source: Primary data processed, 2020 


\subsection{Population and Research Sample}

This study uses a population of 232,229 people in Lubuklinggau City (BPS, 2020). The consideration for choosing Lubuklinggau City is because this area is a transit area that is visited by many people around Lubuklinggau and the level of online-based fraud is rampant during the new normal in Lubuklinggau.

The sample of this study was 400 people who were determined by the slovin formula. The slovin formula is used to reduce the number of populations that are too large but still represent the total population of $100 \%$ (Sujarweni, 2015). The following slovin formula is used with an error rate of $5 \%$ :

$$
\begin{aligned}
& \mathrm{n}=1+\left(\mathrm{N} \times \mathrm{e}^{2}\right) \\
& \text { Sampel slovin }=\mathrm{N}: \mathrm{n}
\end{aligned}
$$

Information:

e2 $=$ Percentage error in the sample

$\mathrm{N}=$ Sample

$\mathrm{n}=$ Sample size

The following is the calculation of the sample in the study:

$\mathrm{n}=1+\left(232.229 \times(0,05)^{2}\right)=580,5725$

Sample of slovin $=232.229: 580,5725=400$ people

Based on the calculation of the sample, this study used a sample of 400 people. This sample is the minimum sample to illustrate that this number has been represented by all the research populations carried out.

\subsection{Research Instruments}

Data were collected from respondents using a questionnaire with a Likert Scale to measure fintech, public financial literacy, and financial inclusion in Lubuklinggau during new normal conditions. Respondents in this study were asked to confirm statements on an ordinal scale in the form of verbal in a number of certain categories, they are:

Table 2. Likert Scale

\begin{tabular}{ll}
\hline Statement & Score \\
\hline Strongly Disagree & 1 \\
\hline Do Not Agree & 2 \\
\hline Agree & 3 \\
\hline Strongly Agree & 4 \\
\hline \multicolumn{2}{c}{ Source: (Sugiyono, 2018) }
\end{tabular}

\subsection{Research Variables and Variable Operational Definitions}

The following is the operational definition of each variable used in the study:

\begin{tabular}{|c|c|c|c|}
\hline No & Variable & Sub-Variable & Variable Type \\
\hline 1 & $\begin{array}{l}\text { The perception of ease } \\
\text { fintech }\end{array}$ & $\begin{array}{l}\text { 1. Easy to use } \\
\text { 2. Easy to operate }\end{array}$ & \\
\hline 2 & $\begin{array}{l}\text { Effectiveness of using } \\
\text { fintech }\end{array}$ & $\begin{array}{l}\text { 1. Benefits of using fintech } \\
\text { 2. Improve user performance }\end{array}$ & \\
\hline 3 & Risk in using fintech & $\begin{array}{l}\text { 1. Risk of human error } \\
\text { 2. Experiencing a loss }\end{array}$ & Endogenous \\
\hline 4 & Interest in using fintech & $\begin{array}{l}\text { 1. Interested in using fintech because of its } \\
\text { attractive features and offers } \\
\text { 2. Interested in using fintech because of } \\
\text { daily needs }\end{array}$ & \\
\hline
\end{tabular}

Table 3. Definition of Operational Variables 


\begin{tabular}{llll}
\hline 5 & Financial Inclusion & 1. Availability/access & \\
& 2. Usage & Exogenous \\
& 3. Quality & \\
& 4. Welfare & Moderation \\
\hline $6 \quad$ Financial Literacy & 1. Basic knowledge of financial management & \\
& 2. Saving and loan & \\
& 3. Insurance & \\
& 4. Investment management &
\end{tabular}

Source: Primary data processed, 2020

\subsection{Data Analysis Techniques}

The analysis technique uses quantitative analysis. The quantitative analysis technique uses a Likert scale with 4 scales to measure each element of the indicator. Data analysis using WarpPLS. includes descriptive statistics, model analysis, and hypothesis.

\section{Analysis and Results}

\subsection{Descriptive Research Data}

Data collection in this study was carried out by distributing questionnaires directly. The application for research permits is aimed at 8 sub-districts in Lubuklinggau City, to give questionnaires to the people directly in each sub-district in each sub-district. A summary of the distribution of questionnaires to sub-districts in Lubuklinggau City is shown in table 4 below:

Table 4. Distribution of Respondents

\begin{tabular}{|c|l|l|l|}
\hline No & District & $\begin{array}{l}\text { Questionnaires Plan to be } \\
\text { Distributed }\end{array}$ & $\begin{array}{l}\text { Number of completed } \\
\text { Questionnaires }\end{array}$ \\
\hline 1 & District of Lubuklinggau Barat I & 55 & 68 \\
\hline 2 & District of Lubuklinggau Barat II & 55 & 66 \\
\hline 3 & District of Lubuklinggau Timur I & 55 & 56 \\
\hline 4 & District of Lubuklinggau Timur II & 55 & 57 \\
\hline 5 & District of Lubuklinggau Utara I & 55 & 47 \\
\hline 7 & District of Lubuklinggau Utara II & 35 & $\mathbf{2 5}$ \\
\hline Total & District of Lubuklinggau Selatan II & 55 & $\mathbf{4 0 1}$ \\
\hline
\end{tabular}

Source: Primary data processed, 2020

The number of questionnaires distributed was 400 copies of 401 respondents. The distribution was done by distributing the questionnaires to each sub-district in Lubuklinggau City. The number is divided by group. In table 4 it can be seen that the number of questionnaires distributed was 400 , with a total return of 401 pieces. The following are the details of the data regarding the level of the questionnaire which are presented in Table 5: 


\begin{tabular}{|l|l|}
\hline Remarks & Number of Questionnaires \\
\hline Distributed Questionnaire & 400 \\
\hline Questionnaire that does not return & 0 \\
\hline Returning Questionnaire & 402 \\
\hline Questionnaire that cannot be processed & 1 \\
\hline Number of questionnaires that can be processed & $\mathbf{4 0 1}$ \\
\hline
\end{tabular}

Source: Primary data processed, 2020

Based on table 5, it is explained that the questionnaire has reached $100 \%$. The distribution of the questionnaires went smoothly without any shortages because filling out the questionnaires was done by going directly to the respondents. The study was conducted for approximately three months to obtain the required number of respondents. Respondents were asked to be willing to fill out the questionnaire on the smartphone provided to completion. There is one questionnaire that cannot be processed because it is not complete so it cannot be processed for data processing.

The following profiles of respondents based on gender and education are presented in:

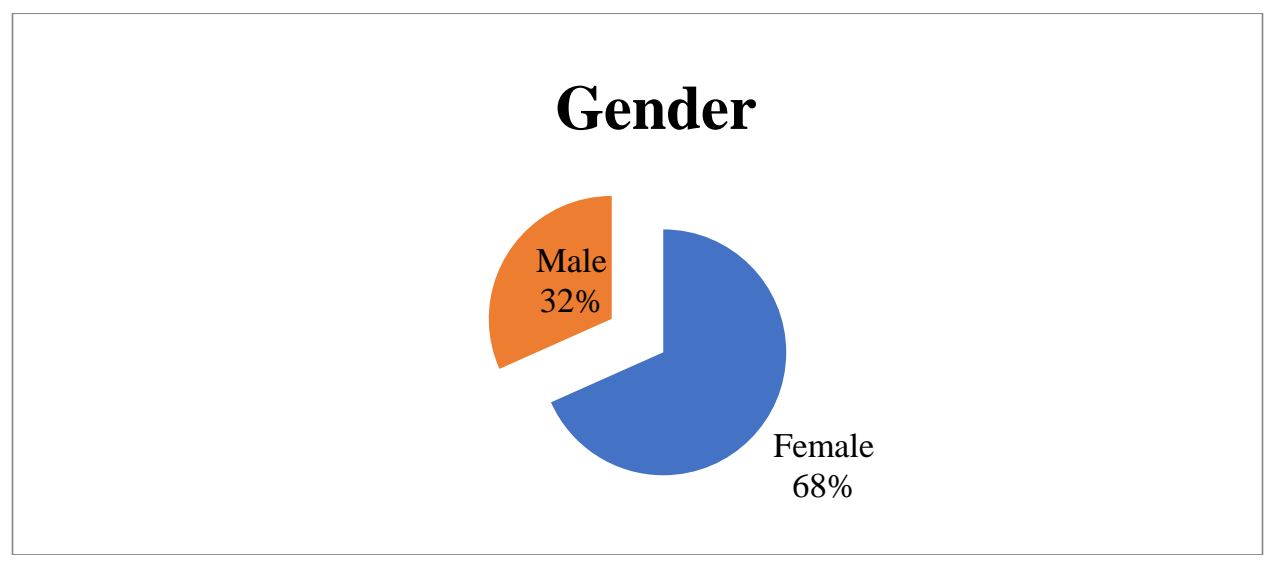

Figure 2. Gender of Respondents

In the picture, it can be seen that the respondents are dominated by women, which is $68 \%$. This was found randomly in the field during data collection, women were more responsive to filling in data and knew more about the research conducted. The rest were $32 \%$ of men who were willing to fill out this questionnaire.

\section{Education}

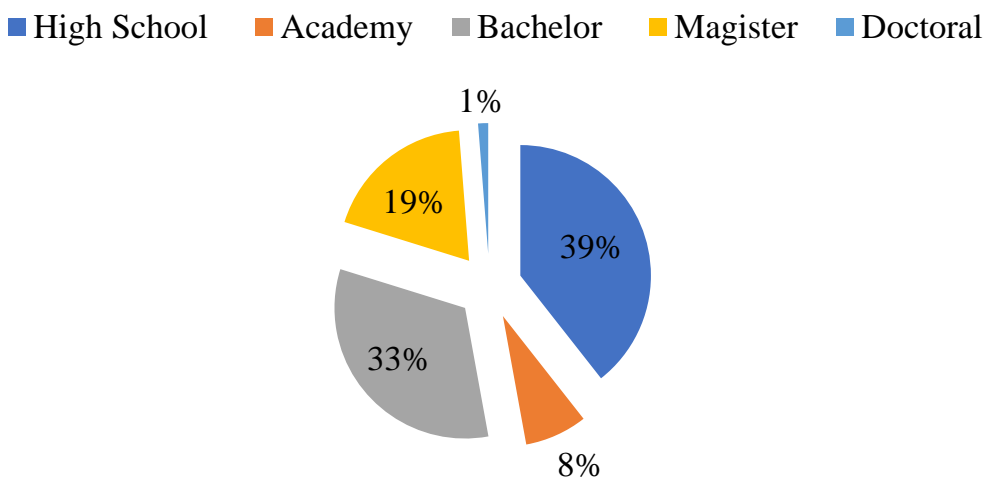

Figure 3. Respondent's Level of Education 
Based on the level of education, the majority of respondents had a high school education level of $39 \%$ and then continued with a bachelor's education at 33\%. Masters is $19 \%$ and Diploma is $8 \%$ while the remaining $1 \%$ is Doctoral education. This illustrates that the use of fintech has been widely used by all lines of education, at least SMA has understood fintech well.

\subsection{Research Results}

Based on the general model elements in the output of WarpPLS 5.0, it explains that the total latent variables in this study are 6 variables, of which the observed variables (manifest variables) are 16 indicators, with details as many as 4 variables for Fintech, each of which contains 2 indicators, 4 indicators for financial literacy, and 4 indicators for financial inclusion. Looking at the evaluation between latent variables, hypothesis testing is carried out by looking at the path coefficient between variables and then comparing the $p$-value with the alpha value (0.05) which is seen in the output of WarpPLS 5.0. The analysis was carried out by including moderating variables to show differences, as described in the following figure:

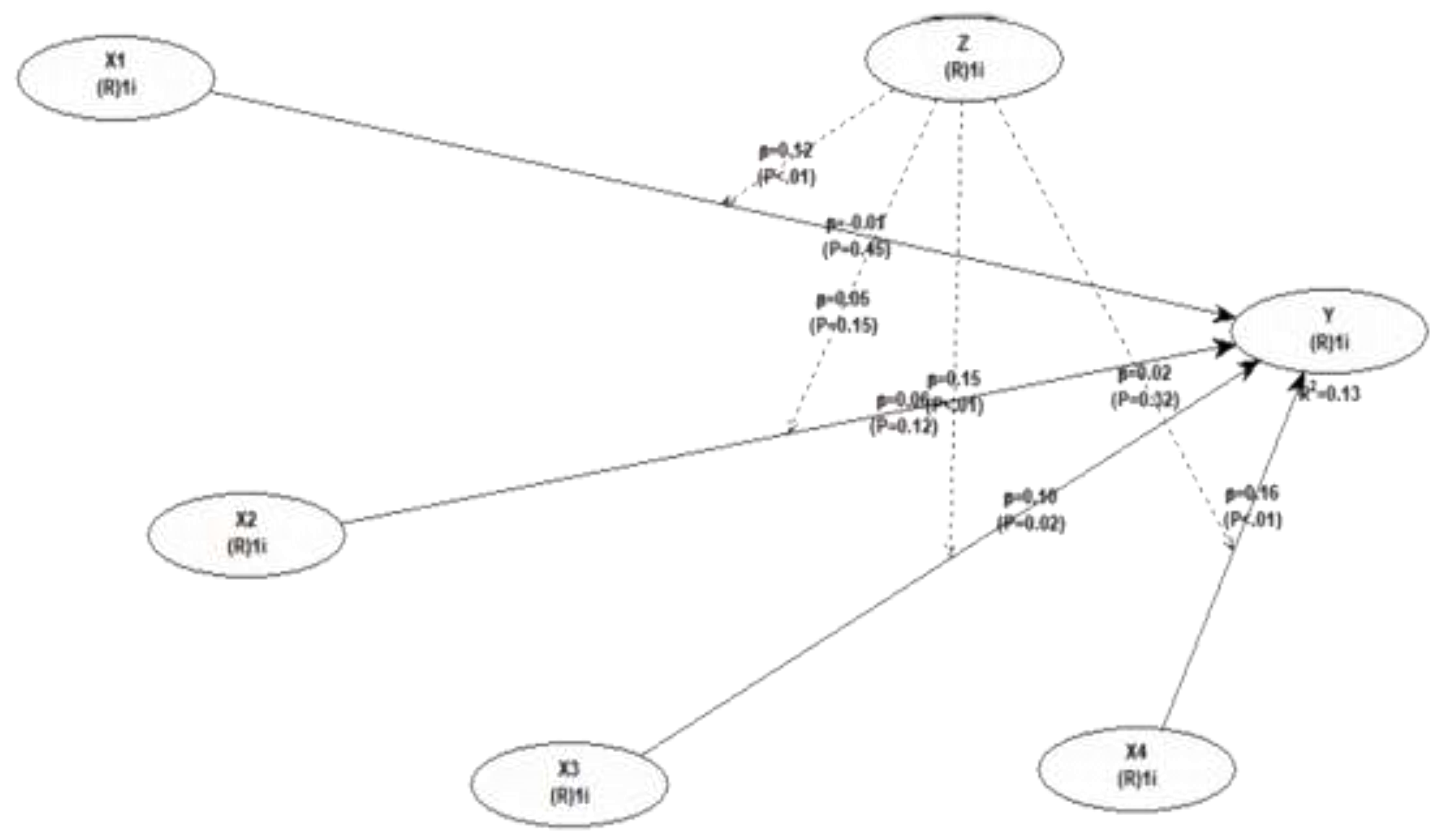

Figure 4. Indirect Effect Research Model Output

Information:

$\mathrm{X} 1$ : Perceived ease of use of fintech

X2: The effectiveness of using fintech

X3: The risk of using fintech

$X 4$ : Interest in transacting using fintech

$Z$ : Financial inclusion

Y: Financial literacy

Based on the model test presented, the R2 value is 0.13 or $13 \%$. Simultaneously, the fintech variable affects the financial inclusion of the people of Lubuklinggau. This research supports previous research that fintech has a direct effect on financial inclusion (Marginingsih, 2021); (Dewi, 2020); (Marini et al., 2020). There are four latent variables, namely perceptions of the ease of using fintech, the effectiveness of using fintech, risk of using fintech, and interest in using fintech which can only affect financial inclusion by $13 \%$, and the rest is influenced by other variables not examined.

H1: Perception of the ease of use of fintech affects financial inclusion

Based on the results of the analysis showing the $p$-value $0.45>0.05$, the first hypothesis is declared rejected. The variable perception of the ease of use of fintech does not have a significant effect on the financial inclusion variable in the Lubuklinggau city community. The variable perception of the ease of use of fintech was found to not affect the financial inclusion variable which can be observed through the path coefficient value or a positive path coefficient of 0.01 . This illustrates that financial inclusion is still 
low and even people do not feel financial inclusion, they assume that using fintech is not an easy thing to do every day in transactions. This study does not support the previous theory which explains that the use of technology provides convenience, increases public perception in increasing trust, and reduces the risk of using fintech.

H2: The effectiveness of using fintech affects financial inclusion

The results of the analysis based on the second hypothesis showed a $p$-value of $0.12>0.05$, so the second hypothesis was rejected. The variable of the effectiveness of using fintech does not have a significant effect on the financial inclusion variable in the Lubuklinggau city community. The variable of the effectiveness of using fintech was found to not affect the financial inclusion variable based on the path coefficient value or path coefficient which has a positive value of 0.06 . Based on Figure 3 . the output of the indirect effect research model, the fintech that developed in the Lubuklinggau city community has not described the increase in public financial inclusion because many of them only use fintech at certain times and prefer to use cash transactions in carrying out financial activities. This hypothesis also does not support the theory used.

\section{H3: The risk of using fintech affects financial inclusion}

Based on the results of the analysis showed a p-value of $0.02<0.05$, the third hypothesis was declared accepted. The risk variable for using fintech has a significant influence on the financial inclusion variable in the Lubuklinggau city community. The risk variable for the use of fintech influences the financial inclusion variable as evidenced by the path coefficient value, which has a positive value of 0.10 . This illustrates that fintech that develops in the Lubuklinggau city community has risks that can harm users because the lack of financial inclusion will have an impact on the risk of using fintech. Users need to understand fintech well and carefully as a form of increasing financial inclusion. This study supports the theory used, namely the Technology Acceptance Model (TAM) Theory and Theory of Planned Behavior (TBP). Based on these two theories, people as users accept technology if it provides benefits for them. Fintech provides convenience but still has risks that can affect individuals' interest or desire to use technology (Sulistiyarini, 2012).

H4: Interest in transacting using fintech affects financial inclusion

Based on the results of the analysis showed a p-value of $0.01<0.05$, the fourth hypothesis was declared accepted. The variable interest in transacting using fintech has a significant influence on the financial inclusion variable in the Lubuklinggau city community. The variable of interest in transacting with fintech influences financial inclusion with a positive path coefficient value of 0.16 . This illustrates that the people of Lubuklinggau are interested in transacting using fintech and this interest increase the financial inclusion of the Lubuklinggau community. This research supports the Technology Acceptance Model (TAM) Theory that every user is interested in using fintech because of the convenience that gives its perception to always use fintech both now and in the future. Fintech's contribution has helped many people who are still not served by formal financial institutions in conducting financial transactions according to their needs. (Marginingsih, 2021).

The following is a summary of the results of hypotheses one to four $(\mathrm{H} 1-\mathrm{H} 4)$ described earlier, as follows:

Table 6. Direct Effect

\begin{tabular}{|l|l|l|l|}
\hline \multirow{2}{*}{ Variable } & \multicolumn{2}{l|}{ Direct Effect } & \multirow{2}{*}{ Remarks } \\
\cline { 2 - 3 } & $\begin{array}{l}\text { Coefficient } \\
\text { Beta }\end{array}$ & P-Value & \\
\hline The perception of ease fintech $\rightarrow$ Financial Inclusion & 0,01 & 0,45 & Rejected \\
\hline Effectiveness of using fintech $\rightarrow$ Financial Inclusion & 0,06 & 0,12 & Rejected \\
\hline Risk in using fintech $\rightarrow$ Financial Inclusion & 0,10 & 0,02 & Accepted \\
\hline Interest in using fintech $\rightarrow$ Financial Inclusion & 0,16 & $<0,01$ & Accepted \\
\hline
\end{tabular}

Source: Primary data processed, 2020

Based on the four hypotheses that have been explained, the risk and interest in using fintech have an influence on financial inclusion that supports the theory used, namely the Technology Acceptance Model (TAM) Theory and Theory of Planned Behavior (TBP). Subsequent analysis analyzes the indirect relationship or moderating effect of the research model. This moderating effect is explained in the next hypothesis. 
This study relates the direct and indirect effects of the use of fintech variables on financial inclusion, and financial literacy as a moderating variable. Based on Figure 4. the output of the indirect effect research model shows the same coefficient value of 0.12 with a p-value below 0.05 . The indirect value also shows a significance $<0.001$ below 0.05 so the fifth hypothesis is accepted. This explains that financial literacy can moderate the perception of the ease of using fintech towards financial inclusion. Financial literacy has had a significant positive influence so that people find it easier to use fintech (Mulasiwi \& Julialevi, 2020). After they understand fintech itself and increase public financial inclusion.

H6: Financial literacy strengthens the effect of the effectiveness of using fintech on financial inclusion

The indirect effect has the same coefficient value of 0.05 with a $p$-value of 0.15 . The indirect value also shows a significance above 0.05 so that the sixth hypothesis is rejected. This explains that financial literacy is not able to moderate the effectiveness of using fintech on financial inclusion. Financial literacy does not play a role in the development of fintech and financial inclusion, so people still think that fintech is still less attractive and prefers to pay in cash.

\section{H7: Financial literacy strengthens the effect of risk using fintech on financial inclusion}

Indirect effects research also shows the same coefficient value of 0.15 with a $p$-value below 0.05 . The indirect value also shows a significance of $<0.001$ below 0.05 so that the seventh hypothesis is accepted. This explains that financial literacy is moderate to the risk of using fintech on financial inclusion. Financial literacy has had a significant positive influence so that people become more confident in using fintech after they understand fintech itself (Mulasiwi \& Julialevi, 2020) and reduce the risk of user error, and increase public financial inclusion.

H8: Financial literacy strengthens the influence of interest in transacting using fintech on financial inclusion

Based on the indirect effect, the coefficient value is smaller than the direct effect of 0.02 with a $p$-value above 0.05 . The indirect value shows a significance of 0.32 above 0.05 so that the eighth hypothesis is rejected. This explains that financial literacy is not able to moderate interest in using fintech for financial inclusion. Financial literacy does not have any effect on public interest in fintech and those who are interested in using fintech will use fintech without considering their financial literacy and financial inclusion.

The following is a summary of the results of hypotheses five to eight $(\mathrm{H} 5-\mathrm{H} 8)$ of the indirect effect model that has been described previously, as follows:

Table 7. Indirect Effect

\begin{tabular}{|l|c|l|l|}
\hline \multirow{2}{*}{ Variable } & \multicolumn{2}{l|}{ Indirect Effect } & \multirow{2}{*}{ Remarks } \\
\cline { 2 - 3 } & $\begin{array}{c}\text { Koefisien } \\
\text { Beta }\end{array}$ & P-value & \\
\hline The perception of ease fintech $\rightarrow$ Financial Inclusion & 0,12 & $<0,01$ & \multirow{2}{*}{ Accepted } \\
\hline Effectiveness of using fintech $\rightarrow$ Financial Inclusion & 0,05 & 0,15 & Rejected \\
\hline Risk in using fintech $\rightarrow$ Financial Inclusion & 0,15 & $<0,01$ & Accepted \\
\hline Interest in using fintech $\rightarrow$ Financial Inclusion & 0,02 & 0,32 & Rejected \\
\hline
\end{tabular}

Source: Primary data processed, 2020

Based on the four hypotheses that have been explained, financial literacy has a moderating effect on the ease of using fintech and the risk of using fintech on financial inclusion. This study supports the theories that have been used, namely the Technology Acceptance Model (TAM) Theory and Theory of Planned Behavior (TBP). Based on the direct effect carried out in the study, the variable interest in the ease of using fintech previously did not affect financial inclusion, but after understanding financial literacy, people became acquainted with and better understood fintech and were willing to use fintech in financial transactions that increase public financial inclusion.

\section{Conclusion}

The perception of the ease of using fintech does not have a significant effect on the financial inclusion variable in the Lubuklinggau city community. This is because people are still not familiar with fintech so they think that using fintech is not an easy thing for them. In addition, the effectiveness of using fintech also does not have a significant effect on the financial inclusion variable in the Lubuklinggau city community. So it is stated that the first and second hypotheses are rejected. Based on the level of risk, the use of fintech has a significant influence on the financial inclusion variable in the Lubuklinggau city community because people think 
that using fintech is something that will be detrimental and has big risks if used. However, based on the results of research, the people of Lubuklinggau City are still interested in using fintech, it is proven that the variable interest in using fintech has a significant influence on the financial inclusion variable.

Based on the indirect analysis, it proves that financial literacy is the moderate perception of the ease of using fintech and reduces the risk of fintech itself on financial inclusion. However, financial literacy is not able to moderate the effectiveness of using fintech and interest in financial inclusion for the people of Lubuklinggau city because the use of fintech is of special interest to the community without the need to consider their literacy understanding.

\section{Implications for Theory and Practice}

This research supports the technology acceptance model (TAM) theory which explains that people usually accept technology in their daily activities as current information that provides additional experiences for them. The use of the fintech experience is a novelty but also provides an overview of the risks that exist in fintech itself. In addition, users are also interested in using fintech for reasons of need and the many interesting features of fintech itself. Fintech provides benefits in the form of convenience so that it can improve individual performance. This research also has implications for users according to the Technology Acceptance Model (TAM) Theory which explains that fintech is used because it is easy to use and implement. This convenience is also relevant to the Theory of Planned Behavior (TBP) that people accept technology if it provides benefits to them. This theory can explain that trust and risk can influence individuals in the interest or desire to use technology. The Theory of Planned Behavior (TBP) has the advantage of being able to analyze situations when individuals cannot control their behavior.

\section{Limitations}

This study only discusses the direct effect of fintech on financial inclusion and the indirect effect of financial literacy as a moderating variable. There is still not much research done in Indonesia, but it has been growing since the Covid-19 pandemic was circulating. The variables discussed only look at people's understanding of the use of fintech, not discussing how far they have understood fintech itself. People only use fintech when needed and this is something new for them. The city of Lubuklinggau is a place of research used in research, the economic development of this city is not as advanced as other big cities so that the use of fintech is not the thing that is most needed by the community.

Acknowledgment: Essential support has been provided for this research by RISTEKDIKTI.

\section{References}

[1] Aaron, M., Rivadeneyra, F., \& Sohal, S. (2017). Fintech: Is this time different? A framework for assessing risks and opportunities for central banks. Bank of Canada Staff Discussion Paper, 10, 1-32.

[2] Anwar, K., Ekonomi, F., \& Pembangunan Fakultas, E. (2017). Pengaruh Inklusi Keuangan Terhadap Pdb Indonesia. Agustus, 2(3), $454-462$.

[3] Bank Indonesia. (2017). Peraturan Bank Indonesia (PBI) No.19/12/PBI/2017 tentang Penyelenggaraan Teknologi Finansial. Gubernur Bank Indonesia, 1-27.

[4] BPS. (2020). Jumlah Penduduk Menurut Jenis Kelamin di Kota Lubuklinggau dan Provinsi Sumatera Selatan Tahun 2015 - 2019. Badan Pusat Statistik Kota Lubuklinggau.

[5] Commerce, U. D. of. (2016). 2016 Top Markets Report Financial Technology Overview and Key Findings. Top Markets Report 2016.

[6] Dewi, M. A. (2020). Gorontalo THE IMPACT OF FINTECH TOWARDS FINANCIAL. Accounting, 3(2), 68-83.

[7] The financial Service Authority Republic of Indonesia. (2018). Sharia Banking Statistics August 2018. Financial Service Authority Republic of Indonesia, Banking Licensing and Information Department, 103.

[8] Holle, M. H. (2019). INKLUSI KEUANGAN; SOLUSI PENGENTASAN KEMISKINAN GUNA DAYA SAING PEREKONOMIAN BANGSA Mohammad H. Holle 1. 01(02), 1-14.

[9] Lee, E. (2018). Kenalan Dulu Dengan Berbagai Jenis Fintech di Indonesia. Kontan.Co.Id.

[10] Marginingsih, R. (2021). Financial Technology (Fintech) Dalam Inklusi Keuangan Nasional di Masa Pandemi Covid-19. Moneter - Jurnal Akuntansi Dan Keuangan, 8(1), 56-64. https://doi.org/10.31294/moneter.v8i1.9903

[11] Marini, M., Linawati, L., \& Putra, R. E. (2020). Peran Fintech terhadap Inklusi Keuangan pada UMKM Tangerang Selatan. Keberlanjutan: Jurnal Manajemen Dan Jurnal Akuntansi, 5(2), 91. https://doi.org/10.32493/keberlanjutan.v5i2.y2020.p91-104

[12] Miswan A. (2019). Perkembangan Dan Dampak Financial Technology (Fintech) Terhadap Industri Keuangan Syariah Di Jawa Tengah. Wahana Islamika: Jurnal Studi Keislaman, 5(1), 32-45.

[13] Mulasiwi, C. M., \& Julialevi, K. O. (2020). Optimalisasi Financial Teknologi (Fintech) terhadap Peningkatan Literasi dan Inklusi Keuangan Usaha Menengah Purwokerto. Performance, 27(1), 12. https://doi.org/10.20884/1.jp.2020.27.1.2284

[14] NDRC. (2014). So what is FinTech? National Digital Research Centre. https://www.ndrc.ie/

[15] OJK. (2013). Salinan Surat Edaran Otoritas Jasa Keuangan Nomor 30 /Seojk.07/2017. Journal of Chemical Information and Modeling, 53(9), 1689-1699.

[16] Pulungan, D. R., \& Ndruru, A. (2019). "Membangun Ekonomi Kreatif yang Berdaya Saing." 132-142. 
[17] Rusdianasari, F. (2018). Kata kunci: Fintech, Inklusi Keuangan, Stabilitas Sistem Keuangan Klasifikasi JEL: G23, E4, E6,. Jurnal Ekonomi Kuantitatif Terapan, 11(2), 244-253.

[18] Sugiyono. (2018). Metode Penelitian Manajemen. Alfabeta.

[19] Sujarweni, W. (2015). Metodologi Penelitian -Bisnis \& Ekonomi. Pustaka Baru Press.

[20] Sulistiyarini, S. (2012). Pengaruh Minat Individu Terhadap Penggunaan Mobile Banking: Model Kombinasi Technology Acceptance Model (TAM) Dan Theory Of Planned Behavior (TPB). Jurnal Ilmiah Mahasiswa FEB, 1(2), 1689-1699.

[21] Titik U, U. (2016). Analisis Tingkat Literasi Keuangan Mahasiswa Fakultas Ekonomi Universitas Negeri Yogyakarta Tahun Angkatan 20122014. Pelita, XI(2), 1-13.

[22] Venkatesh, V., \& Davis, F. D. (2000). A theoretical extension of the Technology Acceptance Model: Four longitudinal field studies. Management Science, 46(2), 186-204. https://doi.org/10.1287/mnsc.46.2.186.11926 